\title{
PENGARUH FASILITAS, KUALITAS PELAYANAN DAN BRAND IMAGE TERHADAP KEPUTUSAN MENGGUNAKAN TRANSPORTASI UDARA
}

\author{
Studi Kasus Pada Konsumen Lion Air Mahasiswa Universitas \\ Teknologi Sumbawa \\ ${ }^{1}$ Dadan Ramdani", ${ }^{2}$ Reza Muhammad Rizqi, ${ }^{3}$ Fendy Maradita \\ Manajemen, Fakultas Ekonomi dan Bisnis, \\ Universitas Teknologi Sumbawa \\ Jl. Raya Olat Maras, Batu Alang, Moyo Hulu, Kabupaten \\ Sumbawa \\ Email: dadanramdani744@gmail.com
}

\begin{abstract}
Abstrak
Ramdani, Dadan. (2020). "Pengaruh Fasilitas, Kualitas Pelayanan dan Brand Image Terhadap Keputusan Menggunakan Transportasi Udara" (studi kasus pada konsumen Lion Air Mahasiswa Universitas Teknologi Sumbawa). Skripsi, Program Studi Manajemen, Fakultas Ekonomi dan Bisnis, Universitas Tekonologi Sumbawa. Pembimbing (I) Reza Muhammad Rizki, M.Ak, (II) Fendi Maradita, M.M.Tujuan penelitian ini adalah untuk mengetahui pengaruh 1) fasilitas terhadap keputusan pembelian. 2) kualitas pelayanan terhadap keputusan pembelian. 3) brand image terhadap keputusan pembelian. Penelitian ini merupakan jenis penelitian kuantitatif, dengan sampel penelitian sebanyak 100 responden. Sampel dalam penelitian diambil dengan dengan menggunakan metode pengambilan sampel purposive sampling yaitu pengambilan yang dilakukan dengan memberikan kuesioner untuk diisi kepada para konsumen mahasiswa Universitas Teknologi Sumbawa yang menggunakan transportasi udara Lion Air. Metode analisis data yang digunakan dalam penelitian ini ialah analisis regresi linier berganda serta menggunakan alat analisis SPSS. Hasil dalam penelitian membuktikan bahwa variabel independen berpengaruh signifikan terhadap varibel dependen.

Kata Kunci : Fasilitas, Kualitas Pelayanan, Brand Image, Keputusan Pembelian.
\end{abstract}

\begin{abstract}
Ramdani, Dadan. (2020). "Influence of facilities, service quality and Brand Image of the decision to use air transportation" (case study on consumer Lion Air students of Sumbawa University technology). Thesis, management study Program, economics and business faculty, Sumbawa Tekonology University. Mentor (I) Reza Muhammad Rizqi, M. Ak, (II) Fendy Maradita, M.M. The purpose of this research is to know the influence of 1) facility against purchasing decisions. 2) Quality of service to purchasing decisions. 3) brand image of the purchase decision. This research is a type of quantitative study, with a research sample of 100 respondents. Samples in the study were taken with the use of purposive sampling method that is taking place by providing questionnaires to be filled to the consumers of Sumbawa Tekonology University who use Lion Air air transport. The data analysis methods used in this study are multiple linear regression analyses as well as using SPSS analysis tools. Results in the study proved that independent variables have significant effect on dependent the.

Keywords: facilities, service quality, Brand Image, decision buying.
\end{abstract}




\section{PENDAHULUAN}

Indonesia merupakan sebuah negara kepulauan yang terbesar di dunia yang terletak dikawasan Asia Tenggara. Negara kepulauan yang terbesar di dunia, Indonesia memiliki banyak potensi baik dalam menciptakan peluang dalam halnya transportasi umum. Melihat hal ini transportasi udara yang menjadi salah satu transportasi utama di negara ini untuk memudahkan masyarakat Indonesia untuk berpindah dari satu kepulauan ke kepulauan lainnya. Dengan hal ini adanya maskapai penerbangan dinilai sangat berpotensi baik bagi penyedia jasa transportasi udara baik untuk distribusi barang atau angkutan penumpang. Pada saat ini transportasi udara menjadi salah satu transportasi yang banyak digunakan masyarakat karena pada saat ini kebutuhan masyarakat akan untuk bertransportasi dalam jarak yang jauh sudah sangat tinggi, sebagian masyarakat ini menganggap transportasi menggunakan pesawat bukanlah hal yang mewah. Hal ini dapat dilihat dari bandara yang ramai dikunjungi oleh para pengguna layanan pesawat. Hal ini dapat terjadi karena munculnya banyak maskapai-maskapai baru yang menawarkan keunggulannya masing-masing.

Didapatkan data dari www.dep.go.id tahun 2016 bahwa perkembangan jasa penerbangan dari tahun ketahun mengalami peningkatan $17 \%$ atau sekitar 45,1 juta orang selama Januari Agustus 2015 dibandingkan periode pada tahun 2014 sebanyak 38,5 juta orang. Dilihat hal ini salah satu transportasi udara menjadi pilihan bagi masyarakat sebagai salah satu transportasi utama untuk melakukan kegiatan berpergian dari satu tempat ketempat yang lain tidak dengan menghabiskan waktu yang cukup lama dan sebagai alat distribusi barang yang cukp efisien tanpa memakan waktu yang cukup lama jika dibandingkan dengan transportasi darat.

Melihat pertumbuhan jumlah penduduk yang didapatkan data dari www.regional.kompas.com tahun 2019 bahwa sebanyak 4 juta penduduk yang meningkat pertahunnya baik untuk bekerja, mengunjungi keluarga maupun berlibur. Dan dengan jumlah penduduk yang sekitar 265 juta berdasarkan data dari www.databoks.com tahun 2018, Indonesia berpeluang baik dalam menjalankan bisnis dibidang transportasi udara dalam halnya angkutan penumpang. Tak dapat dipungkiri dengan banyaknya jumlah jumlah penduduk menjadi suatu peluang bagi perusahaan menciptakan hal yang dapat menjadi sebuah kebutuhan oleh penduduk itu sendiri seperti transportasi udara.

Tabel 1.1. Market Share Penerbangan Domestik Di Indonesia

\begin{tabular}{|l|c|c|}
\hline $\begin{array}{c}\text { Nama } \\
\text { Maskapai }\end{array}$ & $\begin{array}{c}\text { Persentase } \\
(\mathbf{2 0 1 6})\end{array}$ & $\begin{array}{c}\text { Persentase } \\
(\mathbf{2 0 1 7})\end{array}$ \\
\hline Lion Air & $41,6 \%$ & $34 \%$ \\
\hline $\begin{array}{l}\text { Garuda } \\
\text { Indonesia }\end{array}$ & $23,5 \%$ & $20 \%$ \\
\hline $\begin{array}{l}\text { Sriwijaya } \\
\text { Air }\end{array}$ & $10,4 \%$ & $10 \%$ \\
\hline Citylink & $8,9 \%$ & $13 \%$ \\
\hline Wings Air & $4,7 \%$ & $6 \%$ \\
\hline Air Asia & $4,4 \%$ & $1 \%$ \\
\hline Lainnya & $6,5 \%$ & $16 \%$ \\
\hline
\end{tabular}

Sumber : Tito.id, Debhub 2018

Dari data tabel market share berikut maskapai penerbangan tersebut dikuasai oleh Lion Air, Market share sendiri merupakan persentase total dari penjualan suatu perusahaan (dari seluruh sumber) dengan total penjualan jasa ataupun produk dalam industri. Sebagai salah satu market share terbesar di Indonesia, Lion air juga memiliki salah satu penerbangan di Indonesia yang memiliki banyak rute penerbangan disetiap waktu.

Ditengah persaingan antara maskapai penerbangan yang semakin ketat banyak 
upaya-upaya yang dilakukan maskapai penerbangan, tak terkecuali maskapai Lion Air. Sebagai salah satu perusahaan penerbangan nasional, Lion Air masih stabil dalam bersaing dengan maskapai-maskapai lainnya, dalam memberikan pelayanan yang baik untuk dapat menarik pelanggan agar dapat menggunakan jasanya. Lion Air tetap bertahan pada kondisi persaingan maskapai lain yang memiliki citra sebagai maskapai yang memberikan pelayanan pada faktor low cost dan jadwal rute penerbangan yang banyak. Seperti tabel dibawah ini :

Tabel 1.2. Rute Penerbangan Lion Air Domestik Di Indonesia

\begin{tabular}{|c|c|c|}
\hline \multirow{2}{*}{$\begin{array}{c}\text { Rute } \\
\text { Penerbang } \\
\text { an }\end{array}$} & \multicolumn{2}{|c|}{ Jumlah Penumpang } \\
\cline { 2 - 3 } & $\mathbf{2 0 1 8}$ & $\mathbf{2 0 1 9}$ \\
\hline Jakarta & 8.379 .533 & 5.457 .216 \\
\hline Surabaya & 4.521 .482 & 3.503 .834 \\
\hline Denpasar & 3.146 .961 & 2.933 .578 \\
\hline Medan & 2.316 .291 & 1.714 .986 \\
\hline Lombok & 1.634 .031 & 1.310 .605 \\
\hline
\end{tabular}

Sumber Lion Air Grup 2019

Dari data yang yang disajikan diatas, maskapai Lion Air mengalami penurunan penumpang disetiap kota pada tahun 2019. Penumpang Lion air mengalami penurunan dikarenakan kecelakaan pesawat pada akhir tahun 2018. Dimana maskapai lion Air yang memiliki citra kualitas pelayanan ditingkat layanan menengah dan mempunyai citra sebagai low cost.
Tabel 1.3. Harga Penerbangan Domestik Di Indonesia

\begin{tabular}{|l|c|c|}
\hline $\begin{array}{c}\text { Nama } \\
\text { Maskapai }\end{array}$ & $\begin{array}{c}\text { Rute } \\
\text { Penerbangan } \\
\text { Jakarta - } \\
\text { Lombok }\end{array}$ & Rp 911.500/org \\
\hline $\begin{array}{l}\text { Garuda } \\
\text { Indonesia }\end{array}$ & $\begin{array}{l}\text { Jakarta - } \\
\text { Lombok } \\
\text { Cakarta - } \\
\text { Lombok }\end{array}$ & Rp 1.670.600/org $1.268 .600 /$ org \\
\hline Sriwijaya & $\begin{array}{l}\text { Jakarta - } \\
\text { Lombok }\end{array}$ & Rp 1.420.500/org \\
\hline Batik Air & $\begin{array}{l}\text { Jakarta - } \\
\text { Lombok }\end{array}$ & Rp 1.349.500/org \\
\hline
\end{tabular}

Sumber :Lion Air 2019

Pada data tabel diatas, maskapai Lion Air menjadi penerbangan berbiaya rendah dibandingkan dengan maskapai lainnya. Maskapai Lion Air dengan menawarkan banyaknya jumlah rute penerbangan dan banyak tujuan bandara maskapai serta berbiaya rendah. Hal ini menyebabkan maskapai Lion Air berada di bawah dari maskapai lain. Dimana maskapai Lion Air dapat menarik konsumen untuk menggunakan jasa penerbangan maskapai Lion Air tersebut.

Jasa penerbangan dengan fasilitas bagasi berbayar Lion Air sudah memberlakukan penerapan bagasi $0 \mathrm{~kg}$ (nol kilogram) serta mengenakan biaya terhadap kapasitas berat bagasi tercatat untuk penerbangan domestik. Hal ini akan menjadi pertimbangan konsumen dalam menggunakan transportasi udara. Lion Air menawarkan layanan bagasi berbayar untuk para konsumen untuk mempersiapkan rencana perjalanan sesuai kebutuhan membawa bagasi saat berpergian maka dapat membeli bagasi dan bila bepergian tanpa bagasi tidak perlu membayar.

Menurut (Tjiptono, 2012) Kualitas pelayanan merupakan ukuran seberapa bagus tingkat layanan yang diberikan mampu sesuai ekspetasi pelanggan. Untuk bertahan di dunia bisnis maka sebuah perusahaan harus mampu menempatkan strategi dan teknik yang tepat. Langkah penting untuk menemputkan sebuah perusahaan jasa agar lebih unggul salah satunya harus meyediakan jasa yang berkualitas. Perusahaan dituntut untuk terus melakukan perbaikan terutama 
pada kualitas pelayanannya.

Menurut Kotler dan Keller (2009), Brand Image merupakan persepsi dan keyakinan yang dipegang oleh konsumen, seperti yang dicerminkan asosiasi yang tertanam dalam ingatan pelanggan, yang selalu diingat pertama kali saat mendengar slogan dan tertanam dibenak konsumennya. Fenomena yang terjadi di Lion air diketahui bahwa pada tahun 2018 mengalami kecelakaan pesawat. Lion Air sempat mengalami penurunan jumlah penumpang yang cukup drastis namun hal ini hanya terjadi dalam jangka waktu yang tidak terlalu lama. Saat ini Lion Air tetap beroperasional seperti biasa dan jumlah konsumen mulai mengalami kenaikan seperti biasa pada umumnya sebelum terjadi kecelakaan pesawat. Selain itu kualitas pelayanan, brand image penting dijadikan sebagai pertimbangan dalam memilih maskapai penerbangan. Walaupun pesawat lion Air terjadi kecelakaan brand image makapai Lion Air tetap melekat di masyarakat dengan low cost.

Konsumen maskapai Lion Air saat ini sangat kritis karena itu maraknya konsumen dalam memilih atau memilih maskapai untuk menggunakan jasa penerbangan. Menurut Winardi (2010), keputusan pembelian konsumen merupakan titik suatu pembelian dari proses evaluasi. Selain itu keputusan untuk menggunakan jasa merupakan suatu keputusan yang kompleks, selain fasilitas, kualitas pelayanan yang diberikan perusahaan terhadap konsumen, perusahaan harus memiliki citra perusahaan yang baik, untuk melakukan keputusan pembelian atau keputusan penggunaan jasa penerbangan tersebut.

Dengan Lion Air yang memiliki citra sebagai maskapai yang memiliki kualitas pelayanan ditingkat layanan menengah, bukanlah hal yang sulit bagi Lion Air untuk menarik konsumen agar memiliki reputasi baik di mayarakat.
Sebagian dari mahasiswa di pulau sumbawa tentu menginginkan jasa penerbangan karena banyaknya pilihan jadwal penerbangan dengan low cost dan banyak tujuan bandara maskapai Lion Air tersebut. walaupun Lion Air sering terjadi delay atau keterlambatan penerbangan dengan memberikan informasi mengenai jadwal penerbangan yang tertunda dan kurangnya tanggung jawab menangani dari pihak Lion Air dalam menangani kasus seperti kehilangan barang penumpang. Mekanisme kehilangan barang pada kasus kehilangan masih ditemukan sikap saling lempar tanggung jawab tanpa memperhatikan keluhan konsumen. Hal ini dapat menimbulkan dampak negatif Lion Air dibenak konsumen pada fasilitas, kualitas pelayanan, dan brand image.

Berdasarkan uraian di atas, penulis tertarik untuk melakukan penelitian lebih mendalam dengan mengangkat judul "PENGARUH FASILITAS, KUALITAS PELAYANAN DAN BRAND IMAGE TEHADAP KEPUTUSAN MENGGUNAKAN TRANPORTASI UDARA (Studi Kasus Pada Konsumen Lion Air Mahasiswa Universitas Teknologi Sumbawa).

\section{RUMUSAN MASALAH}

1. Bagaimana pengaruh fasilitas terhadap keputusan menggunakan tranportasi udara ?

2. Bagaimana pengaruh kualitas pelayanan terhadap keputusan menggunakan transportasi udara?

3. Bagaimana pengaruh brand Image terhadap keputusan menggunakan transportasi udara?

\section{HIPOTESIS PENELITIAN}

Hipotesis merupakan jawaban sementara dari peneliti terhadap masalah yang diteliti yang perlu dibuktikan kebenarannya. Sugiyono (2019) menyatakan bahwa : hipotesis merupakan jawaban sementara terhadap rumusan masalah penelitian, dimana rumusan masalah penelitian telah dinyatakan dalam bentuk kalimat pertanyaan. Dikatakan sementara, karena jawaban diberikan baru didasarkan pada teori yang 
relavan, belum didasarkan pada faktafakta yang empiris yang diperoleh melalui pengumpulan data.

$\mathrm{H} 1$ : Fasilitas berpengaruh signifikan terhadap keputusan menggunakan transportasi udara.

H2: Kualitas Pelayanan berpengaruh signifikan terhadap keputusan menggunakan transportasi udara.

H3 : Brand image berpengaruh signifikan terhadap keputusan menggunakan transportasi udara.

\section{DEFINISI OPERASIONAL}

\section{Fasilitas}

Menurut Tjiptono dan Chandra, (2011) fasilitas merupakan bentuk fisik atau atmosfir yang dibentuk oleh eksterior dan interior yang disediakan oleh perusahaan dalam membangun rasa aman dan nyaman bagi para konsumen. menyatakan bahwa fasilitas adalah penyediaan perlengkapanperlengkapan fisik untuk memberikan kemudahan kepada konsumen dalam perjalanan menggunakan jasa penerbangan sehingga kebutuhankebutuhan dapat terpenuhi selama menggunakan jasa penerbangan.

Menurut Tjiptono, (2011) indikator fasilitas sebagai berikut :

1) Pertimbangan/perencanaan spesial

2) Tata Perencanaan ruang

3) Perlengkapan/perabotan

4) Pesan -pesan yang disampaikan secara grafis

5) Unsur Pendukung

\section{Kualitas Pelayanan}

Menurut Sunyoto, (2012) kualitas pelayanan utama untuk memberikan kepuasan konsumen serta kemampuan perusahaan dalam menawarkankan jasa untuk memahami bagaimana konsumen memandang mutu yang mereka harapkan, kualitas atau mutu pelayanan dalam jasa industri jasa pelayanan adalah suatu penyajian produk atau jasa sesuai ukuran yang berlaku didalam jasa tersebut sama dengan yang diinginkan dan diharapkan oleh konsumen.

Menurut Adisaputro, (2010) indikator kualitas pelayanan sebagai berikut :

1) Bukti fisik (Tangibles)

2) Kehandalan (Reliability)

3) Ketanggapan (Responsivenes)

4) Jaminan dan Kepastian (Assurance)

5) Perhatian individual (Empathy)

\section{Brand Image}

Menurut Kotler, (2012) Brand Image merupakan persepsi dan keyakinan yang dilakukan oleh konsumen, seperti tercermin dalam asosiasi yang terjadi dalam memori konsumen. Sedangkan menurut Tjiptono, (2011) brand image adalah merupakan serangkaian asosiasi yang dipersepsikan oleh individu sepanjang waktu, sebagai hasil pengalaman langsung maupun tidak langsung atas sebuah merek.

Menurut Kotler, (2012) indikator brand image sebagai berikut :

1) Atribut (Atributes), suatu merek mendatangkan atribut tertentu kedalam pikiran konsumen.

2) Manfaat (Benefits) atribut yang ada harus diterjemahkan menjadi manfaat fungsional dan emosional.

3) Nilai (values), merek juga menyatakan suatu tentang nilai pembuat atau produsen.

4) Budaya (Culture),

5) Kepribadian (personality), merek menjadikan proyeksi dan pribadi tertentu.

6) Pengguna (user), merek dapat mengesankan konsumen.

4. Keputusan Pembelian

Menurut Malau, (2016) keputusan pembelian merupakan tahap proses keputusan dimana konsumen secara aktual melakukan pembelian produk. Konsumen sebagai pelaku utama dalam proses pembelian. Menurut Maulana, (2016) keputusan konsumen adalah motif atau dorongan yang timbul terhadap sesuatu dimana pembeli melakukan pembelian disebabkan adanya kebutuhan dan keinginan.

Menurut malau, (2016) indikator keputusan pembelian sebagai berikut : 
1) Pengenalan masalah

2) Pencarian informasi

3) Mengevaluasi alternatif

4) Keputusan pembelian

5) Perilaku setelah pembelianTahap ini menentukan apakah pembeli puasa atau tidak puas dengan pembelian terletak pada hubungan antara harapan konsumen dan kinerja yang dirasakan langsung pada produk atau jasa.

\section{METODE PENELITIAN}

Jenis Penelitian ini menggunakan metode penelitian kuantitatif melalui pendekatan asosiatif. Metode penelitian adalah cara ilmiah dengan tujuan untuk mendapatkan dan menemukan data valid dibuktikan dan dikembangkan oleh suatu pengetahuan sehingga gilirannya dapat digunakan untuk memahami , memecahkan dan mengantisipasi masalah (Sugiyono,2018). Metode kuantitatif adaalah metode penelitian yang berdsarkan filsafat positivisme, digunakan untuk meneliti pada populasi suatu sampel tertentu.

\section{TEKNIK ANALISIS DATA}

Menurut Ghozali (2011), Uji asumsi klasik bertujuan untuk mengetahui kondisi data yang dipergunakan dalam penelitian. Hal tersebut dilakukan agar diperoleh model analisis yang tepat. Model analisis regresi penelitian ini menyaratkan uji asumsi terhadap data yang meliputi.

\section{HASIL DAN PEMBAHASAN}

\section{Uji Validitas}

Menurut Siregar (2013), uji validitas digunakan untuk mengukur validnya tidak suatu kuesioner, suatu kuesioner dikatakan valid jika pertanyaan pada kuesioner mampu untuk mengungkapkan suatu yang akan diukur oleh kuesioner. Teknik yang digunakan untuk uji validitas pada penelitian ini adalah membandingkan antara nilai $r_{\text {hitung }}$ dengan nilai $r_{\text {table }}$ dengan tarif signifikan 0,05 . Jika di hitung $r_{\text {hitung }} \geq r_{\text {table }}$ ( dengan sig. 0,05) maka instrumen atau item - item pernyataan yang berkorelasi signifikan terhadap skor total (ditanya valid). Perhitungan ini akan dilakukan dengan bantuan program Statistical Package For Social Science (SPSS 16). Untuk menguji validitas instrumen penelitian menggunakan 30 responden dengan rtable 0,361 .

\section{Uji Reliabilitas}

Menurut Arikunto, (2012) reliabilitas adalah suatu indeks yang menunjukan sejauh mana hasil suatu pengukuran dapat dipercaya atau realibel hanya apabila dalam beberapa kali pelaksanaan pengukuran terhadap kelompok subjek yang sama diperoleh hasil yang relatif sama, selama aspek yang diukur dalam diri subjek memang belum berubah. Cara yang digunakan untuk menguji reliabilitas kuesioner adalah dengan menggunakan rumus koefisien Cronbach alpha, pengujian ini dilakukan dengan bantuan program spss 16.

a) Jika nilai koefisien reliabilitas $\geq 0,6$ maka instrumen yang diuji memiliki reliabilitas yang baik/reliable/terpercaya.

b) Jika nilai koefisien reliabilitas $\leq 0,6$ maka instrumen yang diuji tersebut tidak reliable.

\section{UJI ASUMSIK KLASIK}

\section{Uji Multikolinieritas}

Uji multikolinieritas bertujuan untuk mengetahui apakah terdapat gejala korelasi antara variabel indpenden satu dengan variabel independen yang lain. Menurut Ghozali, (2013) adanya multikolinieritas dapat dilihat dari besarnya Variance inflation factor (VIF) dan nilai tolerance value. Yaitu jika tolerance value $\leq 0,10$ atau VIF $\geq 10$ : terjadi multikolinieritas. Uji multikolinieritas pada penelitian ini menggunakan SPSS 16. 
Berdasarkan penjelasan di atas tidak ada variabel yang memiliki nilai VIF lebih besar dari 10 dan nilai tolerance yang lebih kecil dari 10\% (0.1). Maka dapat disimpulkan bahwa tidak ada multikolinieritas antar variabel independen dalam regresi atau dengan kata lain model regresi terbatas dari gejala multikolinieritas.

\section{Uji Normalitas}

Uji normalitas digunakan untuk menguji apakah dalam model regresi dari kedua variabel (variabel dependen dan variabel independen) yang kita pakai mempunyai distribusi normal (Bawono, 2006). Intepretasi yang di gunakan dalam uji normalitas yaitu sig. 0,05 diartikan data berdistribusi normal. Berdasarkan hasil pengujian normalitas uji Kolmogorov-Smirnov. Uji normalitas pada penelitian ini menggunakan SPSS 16.

Berdasarkan penjelasan yang sudah peneliti uraikan dapat dilihat dari nilai sig pada bagian KolmogroveSmirnov yaitu sebesar 0,602 maka dapat dikatakan bahwa distribusi data yang dibuat oleh penulis berdistribusi normal karena nilai KolmogrovSmirnov lebih besar dari 0,05. Hal ini membuktikan bahwa semua variabel dalam penelitian ini berdistribusi normal.

\section{Uji Heteroskedastisitas}

Uji heteroskedastisitas digunakan untuk melihat residual dari model yang berbentuk memiliki varians yang konstan atau tidak (Sanusi, 2011). Uji heteroskedastisitas bertujuan menguji apakah dalam model regresi terjadi ketidak samaan varian dari residual satu pengamatan lain. jika varian dari residual satu pengamatan ke pengamatan lain tetap, maka disebut heomoskedastisitas dan jika berbebeda disebut heteroskedastisitas (Ghazali, 2013).

Jika heteroskedastisitas dalam

penelitian dengan melakukan uji
Glejser atau Absolute Residual dari data.apabila hasil regresi untuk masingmasing variabel menunjukan hasil signifikan diatas tingkat kepercayaan atau signifikan $5 \%$ maka model regresi tidak mengandung adanya heteroskedastisitas. Uji heteroskedastisitas pada penelitian ini menggunakan bantuan program SPSS 16

\section{ANALISA REGRESI LINIER BERGANDA}

Menurut Tanzeh, (2012) analisis regresi pada dasarnya adalah studi mengenai ketergantungan variabel dependen (terikat) dengan satu atau lebih variabel independen (variabel bebas), dengan tujuan untuk mengestimasi atau memprediksi rata - rata populasi atau nilai - nilai variabel dependen berdasarkan nilai variabel independen yang diketahui.

Menurut Sugiyono, (2018) analisis regresi linier berganda digunakan peneliti, bila peneliti ini bermaksud meramalkan bagaimana keadaan (naik turunnya) variabel dependen (kriterium), bila dua atau lebih variabel independen sebagai faktor prediktor dimanipulasi (dinaik turunkan nilainya). Uji regresi linier berganda pada penelitian ini menggunakan bantuan program SPSS 16.

Dengan menggunakan teknik analisis ini dapat mengetahui hubungan antara dari variabel $X$ (independen) yaitu fasilitas, kualitas pelayanan, brand image terhadap keputusan konsumen variabel $Y$ (Dependen). Adapun persamaan regresi linier berganda menurut Sugiyono, sebagai berikut:

Keterangan

$$
y=a+b_{1} x_{1}+b_{2} x_{2}+b_{3} x_{3}+e
$$

y : Variabel keputusan menggunakan

a : Konstanta

$\mathrm{X}_{1}$ : Variabel Fasilitas

$\mathrm{X}_{2}$ : Variabel Kualitas Pelayanan

$\mathrm{X}_{3}$ : Variabel Brand Image

b1 $_{1}$ : Koefisien Regresi Variabel Fasilitas

b2 : Koefisien Regresi Kualitas Pelayanan

b3 : Koefisien Regresi Brand Image

e : Standar Error 


\section{PEMBAHASAN}

1. Pengaruh Fasilitas terhadap keputusan pembelian

Hasil pengujian menunjukan fasilitas (X1) dengan nilai $t_{\text {hitung }} 2.371>$ dari $t_{\text {table }} 1.984$ dengan nilai signifikansi $0,020<$ 0,05 , artinya fasilitas berpengaruh signifikan terhadap keputusan pembelian. Fasilitas merupakan bentuk fisik atau atmosfir yang dibentuk oleh eksterior dan interior yang disediakan oleh perusahaan dalam membangun rasa aman dan nyaman bagi para konsumen. menyatakan bahwa fasilitas adalah penyediaan perlengkapan fisik untuk memberikan kemudahan kepada konsumen dalam perjalanan menggunakan jasa penerbangan sehingga kebutuhan-kebutuhan dapat terpenuhi selama menggunakan jasa penerbangan (Tjiptono dan Chandra, 2011).

Kondisi ini mengindikasikan bahwa semakin baik fasilitas yang disediakan oleh maskapai Lion Air tersebut seperti memberikan pesawat terbaru, free bagasi $7 \mathrm{~kg}$ dan memiliki buku panduan dalam melakukan penerbangan bersama maskapai Lion Air. Maka akan semakin meningkat keputusan pembelian yang menggunakan jasa penerbangan maskapai Lion Air tersebut.

Hasil penelitian ini sejalan dengan penelitian yang telah dilakukan oleh wahyu (2016), yang menunjukan bahwa fasilitas berpengaruh signifikan terhadap keputusan pembelian (studi kasus pada konsumen PT. Kereta Api Indonesia Daerah Operasional VI Yogyakarta). Jasa penerbangan dengan fasilitas yang memadai tentu menunjang konsumen menggunakan transportasi udara. Hal ini pasti akan menjadi pertimbangan konsumen yang menggunakan tranportasi udara (Tjiptono, 2011).

2. Pengaruh kualitas pelayanan terhadap keputusan pembelian

Hasil yang disajikan pada Tabel di atas menunjukan bahwa variabel kualitas pelayanan (X2) dengan nilai $t_{\text {hitung }} 2.600$ $>1.984$ dari $t_{\text {table }}$ dengan nilai signifikansi $0,011<0,05$ kualitas pelayanan berpengaruh signifikan terhadap keputusan pembelian. Kualitas pelayanan utama untuk memberikan kepuasan konsumen serta kemampuan perusahaan dalam menawarkankan jasa untuk memahami bagaiman konsumen memandang mutu yang mereka harapkan, kualitas atau mutu pelayanan dalam jasa industri jasa pelayanan adalah suatu penyajian produk atau jasa sesuai ukuran yang berlaku didalam jasa tersebut sama dengan yang diinginkan dan diharapkan oleh konsumen (Sunyoto, 2012)

Artinya kualitas pelayanan digunakan dapat meningkatkan keputusan pembelian konsumen. Dengan kondisi ini kualitas pelayanan yang diberikan maskapai Lion Air semakin baik pelayanan yang dilakukan oleh pramugari atau pramugaras seperti kerapian bepakaian dan kesopanan untuk menarik konsumen dalam menggunakan jasa penerbangan. Maka akan semakin meningkat keputusan pembelian yang menggunakan jasa penerbangan maskapai Lion Air.

Hasil penelitian ini sejalan dengan penelitian pamungkas (2017), yang menunjukan bahwa kualitas pelayanan berpengaruh signifikan terhadap keputusan pembelian tiket maskapai penerbangan Citilink. Universitas Negeri Semarang. Kualitas pelayanan merupakan ukuran seberapa bagus tingkat layanan yang diberikan mampu sesuai ekpetasi pelanggan (Tjiptono,2011).

3. Pengaruh brand image terhadap keputusan pembelian

Hasil yang disajikan pada Tabel di atas menunjukan bahwa variabel brand image (X3) dengan nilai $t_{\text {hitung }} 2.526>1.984$ 
dari $t_{\text {table }}$ dengan nilai signifikansi $0,011<0,05$ brand image berpengaruh signifikan terhadap keputusan pembelian. Menurut Kotler, (2012) Brand Image merupakan persepsi dan keyakinan yang dilakukan oleh konsumen, seperti tercermin dalam asosiasi yang terjadi dalam memori konsumen (Kotler, 2012).

Dengan kondisi ini maskapai Lion Air masih mempunyai reputasi baik dikalangan masyarakat dengan jadwal penerbangan lebih banyak dari maskapai lain. dan maskapai Lion Air mempunyai citra berbiaya rendah dalam penerbangan. Maka akan semakin meningkat keputusan pembelian yang menggunakan jasa penerbangan maskapai Lion Air. Hasil penelitian ini sejalan yang dilakukan oleh Meisyaroh (2015), yang menunjukan bahwa variabel brand image berpengaruh signifikan terhadap keputusan pembelian tiket maskapai Air Asia. Brand image merupakan persepsi dan keyakinan yang dipegang oleh konsumen, seperti dicerminkan asosiasi yang tertanam dalam ingatan pelanggan, yang selalu ingat pertama kali saat mendengar slogan dan tertanam dibenak konsumennya Kotler dan Keller (2009).

4. Pengujian Adjusted $R^{2}$

Adjusted $R^{2}$ dengan nilai 0,253 atau $25,3 \%$. Jadi dikatakan bahwa nilai $25,3 \%$ keputusan pembelian ( $Y$ ) yang dapat dijelaskan oleh variabel independen yaitu fasilitas, kualitas pelayanan dan brand image. Sedangkan sisanya $74,7 \%$ dijelaskan oleh variabel lain diluar model yang tidak dijelaskan dalam penelitian ini. $74,7 \%$ merupakan hasil perhitungan yang menyatakan bahwa 74,7\% dijelaskan oleh variabel lain diluar model yang tidak dijelaskan dalam penelitian ini. Seperti harga yang mempunyai pengaruh terhadap keputusan pembelian menandakan bahwa sebagian besar konsumen berpendapat bahwa harga jasa penerbangan maskapai Lion Air terjangkau sesuai dengan fasilitas, kualitas pelayanan dan kebutuhan transportasi yang dirasakan oleh konsumen. Penetapan harga secara tepat merupakan faktor penting dalam menentukan kesuksesan perusahaan jangka pendek dan jangka panjang (Tjiptono, 2011).

\section{KESIMPULAN}

a. Berdasarkan penelitian pada konsumen maskapai Lion Air Mahasiswa Universitas Teknologi Sumbawa yang telah menggunakan jasa penerbangan maka diketahui fasilitas berpengaruh signifikan terhadap keputusan pembelian. Dalam penelitian ini semakin baik fasiltas yang diberikan oleh maskapai Lion Air, maka akan semakin meningkat keputusan pemebelian dalam menggunakan jasa penerbangan tersebut.

b. Berdasarkan penelitian pada konsumen maskapai Lion Air Mahasiswa Universitas Teknologi Sumbawa yang telah menggunakan jasa penerbangan maka diketahui kualitas pelayanan berpengaruh signifikan terhadap keputusan pembelian. Dalam penelitian ini semakin baik kualitas pelayanan yang diberikan oleh masakapai Lion Air, maka akan semakin meningkat keputusan pembelian dalam menggunakan jasa penerbangan tersebut.

c. Berdasarkan penelitian pada konsumen maskapai Lion Air Mahasiswa Universitas Teknologi Sumbawa yang telah menggunakan jasa penerbangan maka diketahui brand image berpengaruh signifikan terhadap keputusan pembelian. Dalam penelitian ini semakin baik brand image (citra merek) yang dimiliki oleh maskapai Lion Air, maka akan semkin meningkat keputusan pembelian dalam menggunakan jasa penerbangan tersebut. 


\section{SARAN}

a. Bagi peneliti dengan topik sejenis disarakan untuk melakukan kajian lebih lanjut dengan memasukkan variabel bebas seperti harga, promosi, dan lain-lain.

b. Bagi peneliti, selanjutnya diharapkan dapat terus memperdalam dan mengaplikasikan teori pemasaran dengan menambah variabelvariabel yang belum diteliti dalam penelitian ini, misalanya kepuasan konsumen.

c. Bagi konsumen sebaiknya dalam melakukan pembelian atau menggunakan jasa penerbangan konsumen tidak memandang negatif pada maskapai Lion Air melainkan melihat juga dari faktor perbaikan fasilitas, kualitas pelayanan dan brand image yang terus dilakukan maskapai Lion Air sehingga konsumen merasakan perasaan yang teanang dan nyaman selama penerbangan.

\section{DAFTAR PUSTAKA}

Adisaputro Gunawan, 2010. Manajemen Pemasaran. Edisi 1. Yogyakarta : UPP STIM YKPN.

Alma Buchari, 2014. Manajemen Pemasaran Dan Pemasaran Jasa. Bandung : Alfabeta

Andi Hartik, Kepala BKKBN: Laju Pertumbuhan Penduduk 4 Juta Per Tahun, Idealnya 2 Juta" diperoleh 15 november 2019, dari www.regional.kompas.com.

Arikunto, S. 2012. Prosedur penelitian suatu pendekatan praktis. Jakarta : Rineka Cipta.

Assauri Sofjan, 2013. Manajemen Pemasaran. Edisi 1 jilid 12. Jakarta : RajaGrafindo.

Buchory, Herry. \& Saladdin, Djaslim. 2010. Manajemen Pemasaran. Bandung : Linda Karya

Databoks, "2018, Jumlah Penduduk
Indonesia Mencapai 265 Juta Jiwa". Diperoleh 16 november 2019, dari www.databoks.katadata.co.id.

Dephub, 2016. "On time Performance 15 Maskapai Berjadwal Periode JuliDesember 2015 sebesar 77,16\%" diperoleh 15 november 2019, dari www.dephub.go.id.

Ghozali, I. (2013). Aplikasi Analisis Multivariat Dengan Program IBM SPSS. Semarang:Badan Penerbit Universitas Diponegoro.

Herliyana, 2013. "Pengaruh harga tiket Online dan pelayanan terhadap keputusan menggunakan transportasi pesawat terbang Lion Air" Semarang. Universitas Negeri Semarang.

Kotler, P \& Keller, L, K. 2013. Manajemen Pemasaran. Edisi 13 jilid 1. Jakarta: Erlangga.

Kotler, P \& Keller, L,K. 2008. Manajemen Pemasaran. Edisi 13 jillid 2. Jakarta : Erlangga.

Kotler, P, \& Armstrong, G. 2013. Prinsip prinsip Pemasaran. Edisi 12. Jakarta : Erlangga

Kotler, Philip. 2012. Manajemen Pemasaran. Jakarta : Indeks

Malau, Harman. 2017. Manajemen Pemasaran Teori Dan Aplikasi Pemasaran Era Tradisional Sampai Era Modernisasi Global. Bandung: Alfabeta.

Manuanza, Afianka. Pengaruh Brand image terhadap Keputusan Pembelian (studi kasus pada maskapai lion air low cost carrier), Jakarta : universitas indonesia

Meisyaroh, Siti. 2015. Pengaruh Brand Image Air Asia terhadap keputusan pembelian tiket maskapai penerbangan pegangsaan dua. Jakarta. Institut dan Informatika.

Pamungkas, Satrio. 2017.Pengaruh tarif, citra merek, kualitas pelayanan terhadap keputusan pembelian tiket pembelian maskapai penerbangan Citilink. Semarang. Universitas Negeri Semarang. 
Sanusi, Anwar. 2011. Metodologi Penelitian Bisnis. Jakarta : Salemba Empat

Schiffman Leon, \& Kanuk Leslie Lazar. 2013. Consumer Behavior. Prentice Hall : New jersey.

Sugiyono, (2018). Metode Penelitian Kuantitatif Kualitatif Dan R\&D. Bandung : Alfabeta.

Sujarweni, Wiratna. 2012. Metode Penelitian. Yogyakarta : Pustaka Baru Press.

Sunyoto, Danang. 2012. Konsep Dasar Riset Pemasaran Dan Perilaku Konsumen. Yogyakarta: CAPS (Center For Publishing Service)

Tjiptono, F. \& Chandra, G. 2011. Service, Quality \& Satisfaction. Yogyakarta:CV. Andi Offise.

Tjiptono, Fandy. 2011 Strategi Pemasaran. Edisi 3. Yogyakarta : AN

Wahyu, Adi. 2016. Pengaruh kualitas pelayanan dan fasilitas terhadap keputusan pembelian (studi kasus pada konsumen PT. Kereta Api Indonesia Daerah Operasional VI Yogyakarta) Yogyakarta. Universitas Sanata Dharma. 
JURNAL MANAJEMEN DAN BISNIS VOL.2.NO.2 2019

http://jurnal.uts.ac.id 